\title{
Key Plant, Key Pests: Azalea (Rhododendron spp.) ${ }^{1}$
}

\author{
Juanita Popenoe, Caroline R. Warwick, Jacqueline Bourdon, and David J. Norman²
}

\section{Key Plant: Azalea (Rhododendron spp.)}

Azaleas are rhododendrons whose flowers have five stamens. Azaleas are well-known for their spectacular flowering display and shade tolerance and are commonly used as landscape plants in north and central Florida. Azaleas are widespread across the United States, thriving in USDA hardiness zones 5-9. With over 10,000 known cultivars, azalea colors include hot pink, coral, pale pink, fuchsia, purple, orange, red, white, as well as many bicolor varieties. Although traditionally a spring bloomer, with central Florida climates and new cultivars available, they frequently bloom in spring and fall, with their flowers lasting several weeks. Azaleas are known for their ability to tolerate various levels of light, growing from moderate sun to full shade conditions. Because of this, they are often planted under large oak canopies. Azaleas are traditionally slow-growing and prefer well-drained acidic soil; they do not tolerate alkaline soils, salt drift, drought, poor soil drainage, or saline irrigation water (Brown 2018).

\section{Key Pests: Azalea}

This series of Key Plant, Key Pests publications are designed for Florida gardeners, horticulturalists, and landscape professionals to help identify common pests associated with common Florida flora. This publication, the sixth in the Key Plant, Key Pests series, helps identify the most common pests found on the azalea.

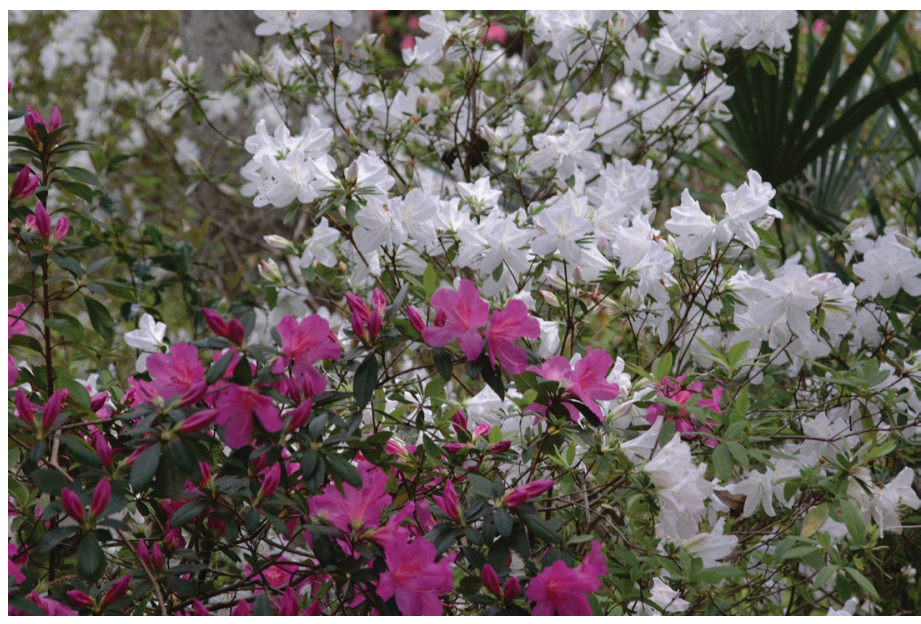

Figure 1. Azaleas with both fuchsia and white petals. Credits: UF/IFAS

This publication provides information and general management recommendations for the azalea caterpillar, azalea lace bug, azalea leafminer, rhododendron gall midge, azalea gall, cercospora leaf spot, mushroom root rot, ovulinia petal blight, wet root rots, and iron chlorosis. For a more comprehensive guide of woody ornamental insect management, download the current Professional Disease Management Guide for Ornamental Plants (http://edis.ifas. ufl.edu/pp123) or the Integrated Pest Management in the Commercial Ornamental Nursery Guide (http://edis.ifas. ufl.edu/ig144).

1. This document is ENH1303, one of a series of the Environmental Horticulture Department, UF/IFAS Extension. Original publication date October 2018. Visit the EDIS website at https://edis.ifas.ufl.edu for the currently supported version of this publication.

2. Juanita Popenoe, multi-county commercial fruit production agent IV; Caroline Roper Warwick, science communications specialist; Jacqueline Bourdon, communications intern; and David J. Norman, professor; UF/IFAS Mid-Florida Research and Education Center, Apopka, FL 32703. 


\section{Azalea Caterpillar RECOGNITION}

When azaleas are missing significant amounts of foliage, the azalea caterpillar may be the cause. Often the caterpillar is not detected until most of the plant has been defoliated. Tips and margins of leaves can also appear rolled, damaged by feeding larvae inside.

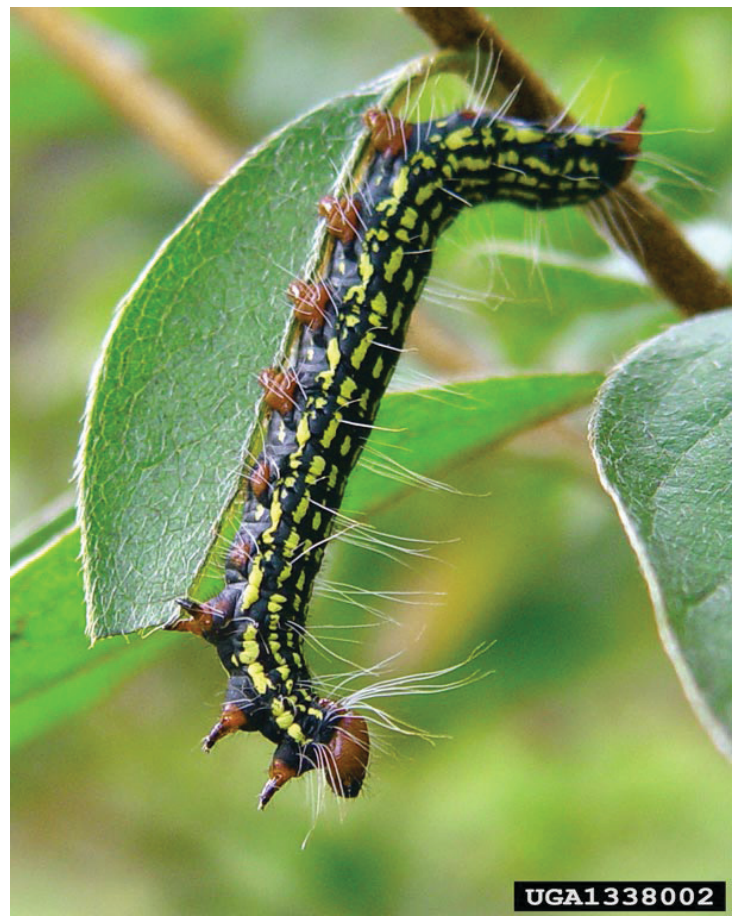

Figure 2. An adult azalea caterpillar.

Credits: Chris Evans, University of Illinois, Bugwood.org (https://www. ipmimages.org/browse/detail.cfm?imgnum=1338002)

\section{IDENTIFICATION}

The caterpillars are easily found because they live in groups on the plant; they are recognized by their red heads, red posterior segments, and yellow stripes. When disturbed, the individual caterpillars react by forming a " $U$ " shape. They grow to $2 \frac{1}{2}$ inches long before dropping to the soil to pupate. The adult moth is light brown with a wing span of 13/4 inches (Dekle and Fasulo 2017).

\section{CONTRIBUTING FACTORS}

Primarily a late summer pest in central Florida, there are two generations per year, with the second being more prolific. Most of the damage occurs from August through October. Rhododendron spp. are the only known hosts in Florida.

\section{MANAGEMENT RECOMMENDATIONS}

Remove and destroy infested branches. Use Bacillus thuringiensis $(\mathrm{Bt})$ or other approved insecticides on small caterpillars. The caterpillars can also be removed by hand.
Although the caterpillars are hairy they are harmless to humans.

\section{Azalea Lace Bug RECOGNITION}

Azalea lace bug (Stephanitis pyrioides (Scott) damage is recognized as a stippled, silvery, chlorotic, or bleached appearance of the leaves. The symptoms are caused by the insects' piercing-sucking type of feeding on the undersides of leaves. Adults are $1 / 8$ to $1 / 4$ inches long and have cream colored bodies with transparent, lacy wings held flat on the back. The immatures lack wings but are covered with spines. Eggs are inserted into the undersides of leaves. Shiny black eggs or fecal spots are often observed (Gyeltshen \& Hodges 2006).

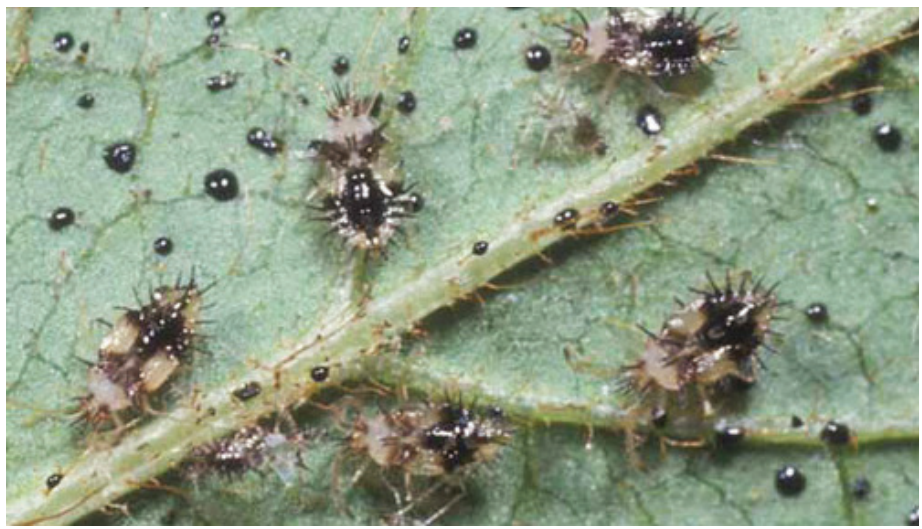

Figure 3. Azalea lace bug nymphs.

Credits: James L. Castner, UF/IFAS

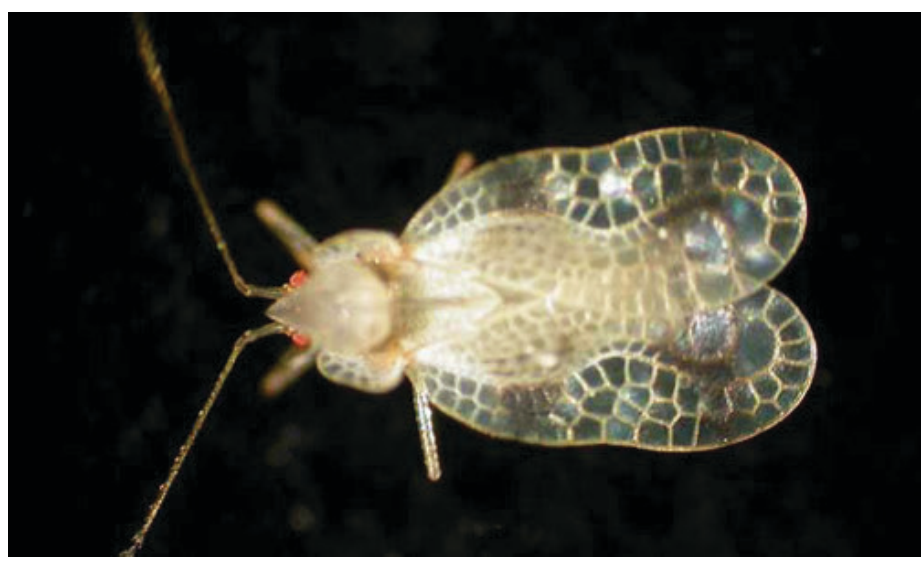

Figure 4. Adult azalea lace bug.

Credits: Jamba Gyeltshen, UF/IFAS

\section{CONTRIBUTING FACTORS}

The azalea lace bug is host specific and will not feed on other plants. There are three to five generations each year. Full-sun locations are often the most severely damaged. Azalea lace bugs have been noticed to particularly favor evergreen azalea varieties. 


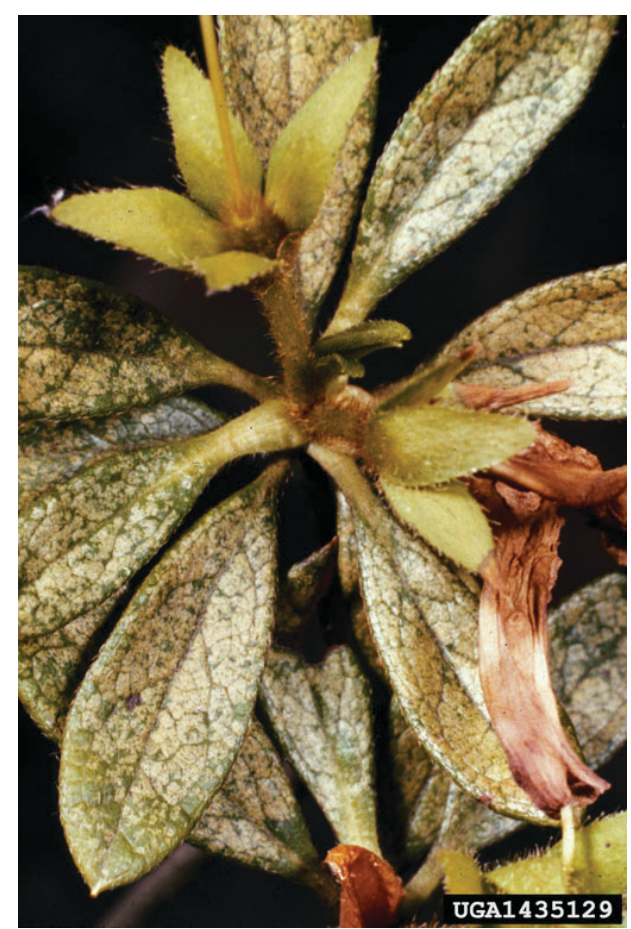

Figure 5. Damage caused by the sucking of azalea lace bugs. Credits: Clemson University, USDA Cooperative Extension Slide Series, Bugwood.org (https://www.ipmimages.org/browse/detail. cfm?imgnum=1435129)

\section{MANAGEMENT RECOMMENDATIONS}

Monitor lace bug populations weekly, checking the undersides of leaves with a hand lens, as initial damage may not be apparent. Often a hard jet of water from a hose, directed on the undersides of the foliage, can dislodge insects, although any remaining may damage the plant. Spring is the best time for control using insecticidal soap, horticultural oil, neem oil, or approved insecticides, applying to the underside of leaves for optimal coverage when needed. Control early in the season when populations are low for best results.

\section{Azalea Leafminer RECOGNITION}

The azalea leafminer (Caloptilia azaleella) is a larva of a tiny yellow- and purple-marked moth. The larvae mine between the upper and lower leaf surfaces until they are about half-grown. Once they emerge, the leaf tips or margins fold over themselves while they continue to feed on the leaves. Damage appears as dry, brown spots on the leaves. Mature larvae are about $1 / 2$ inch long and yellowish brown. They pupate inside the mines (Dekle 2007). In Florida, the larvae are found every month in the year; however, azalea leafminers are most prevalent in the spring and summer months.

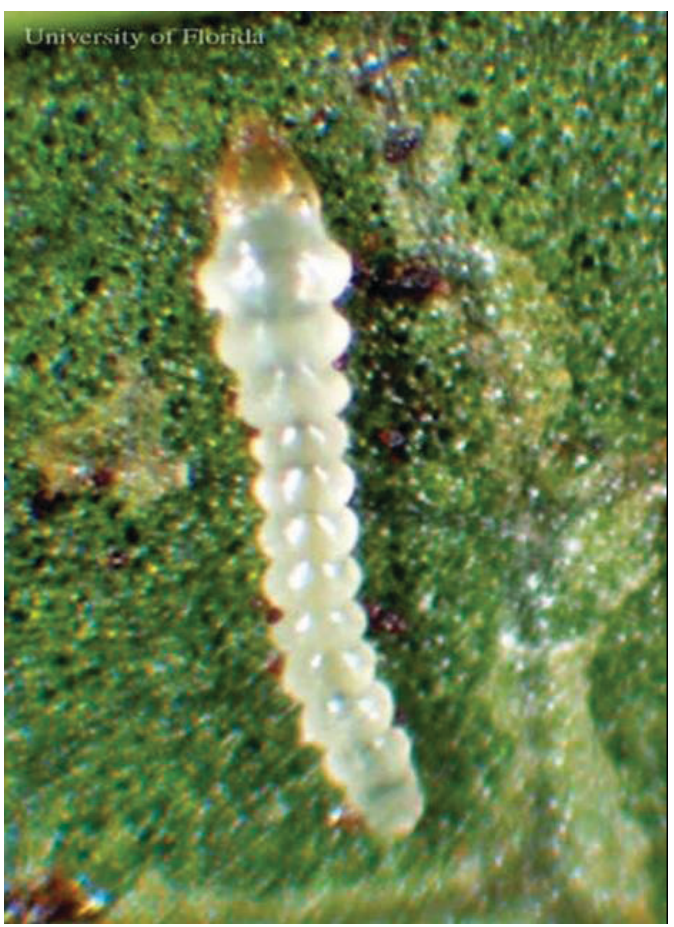

Figure 6. Mature larva of the azalea leafminer.

Credits: Russell F. Mizell, UF/IFAS.

\section{MANAGEMENT RECOMMENDATIONS}

Leafminers can be difficult to control because they are protected by leaf tissue. Prune and destroy infested leaves and branches, maintaining health plants that are able to outgrow the damage. For a heavy infestation, a systemic insecticide may be used; however, chemical controls are not useful once the leafminer has completed its development. The species can also be controlled biologically, with at least three parasitoids from the genus Sympiesis Förster (Hymenoptera: Eulophidae) attacking the pupa.

\section{Rhododendron Gall Midge (Clinodiplosis rhododendri) RECOGNITION}

The gall midge attacks new buds and leaves causing leaf curling and distortion. Terminal leaves become small and malformed and may form a "witches broom." Midges are very small dipterous insects, and are difficult to see, even with magnification. Sublethal doses of glyphosate may cause similar symptoms.

\section{CONTRIBUTING FACTORS}

Damage caused by midges is usually first noticed in spring when new vegetative growth is initiated. The damage is done by the larval stages. There can be several generations of insects per year. Unless overhead irrigated, lack of rainfall can slow down the development of the insects. 


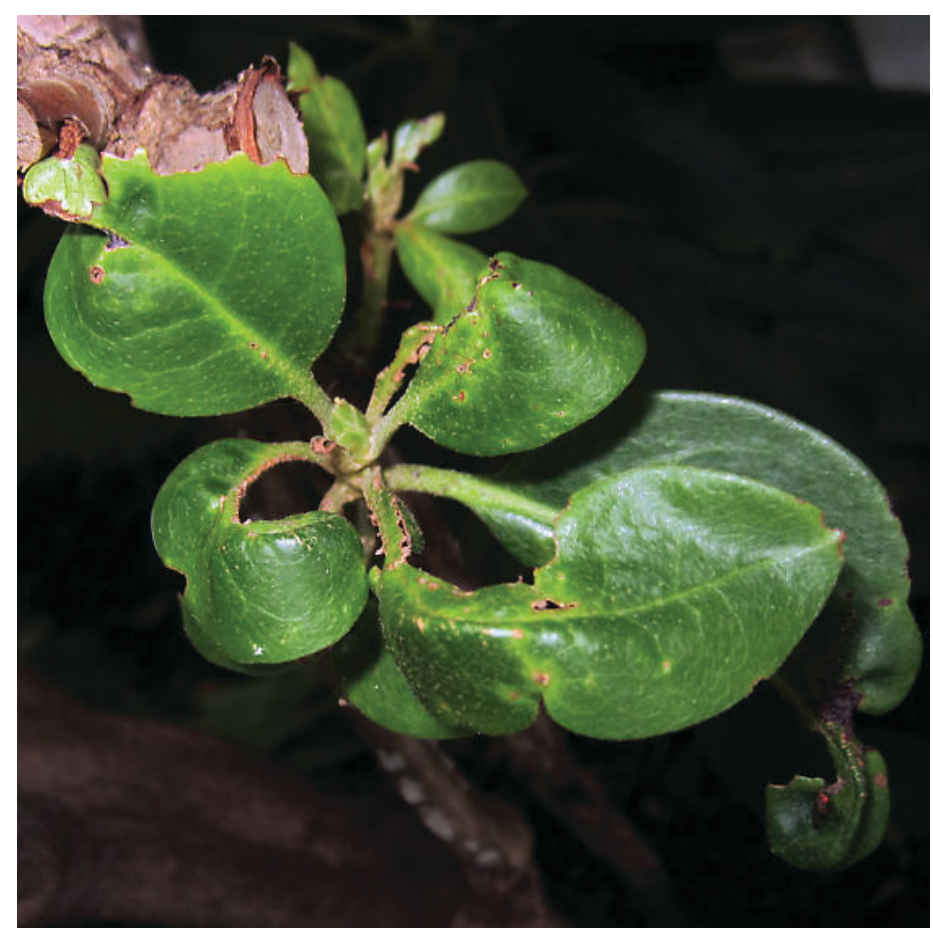

Figure 7. Damage caused by Rhododendron gall midge.

Credits: John R. Maxwell, BugGuide.net (https://bugguide.net/node/ view/837531/bgpage)

\section{MANAGEMENT RECOMMENDATIONS}

Approved insecticides timed to coincide with bud break can be used to control midges, but the symptoms will remain even after the midges are gone. Soil drenches or applications of labeled insecticides are effective. Prune out symptomatic terminals or branches.

\section{Spider Mites}

\section{RECOGNITION}

Tiny (less than 1/50 inch) eight-legged mites are found most commonly on the undersides of leaves. Eggs, cast skins, and silken webs are also signs of mites. Mites feed with piercing-sucking mouthparts, causing the upper sides of leaves to exhibit a stippled or bronzed appearance. Common mite pests of azaleas include both southern red mites and twospotted spider mites. Southern red mites are named for their bright red color, whereas twospotted spider mites have dark spots on both sides of the abdomen (Fasulo and Denmark 2016; Denmark, Welbourn, and Fasulo 2015).

\section{CONTRIBUTING FACTORS}

Southern red mites are most prevalent in cool, moist conditions, whereas two-spotted spider mites prefer hot, dry weather.

\section{MANAGEMENT RECOMMENDATIONS}

Knock branches against a white piece of paper to monitor for mites. Check for predaceous mites as well, which are larger and move more quickly. Insecticidal soaps, horticultural oils, or approved miticides may be used to control mites when necessary.

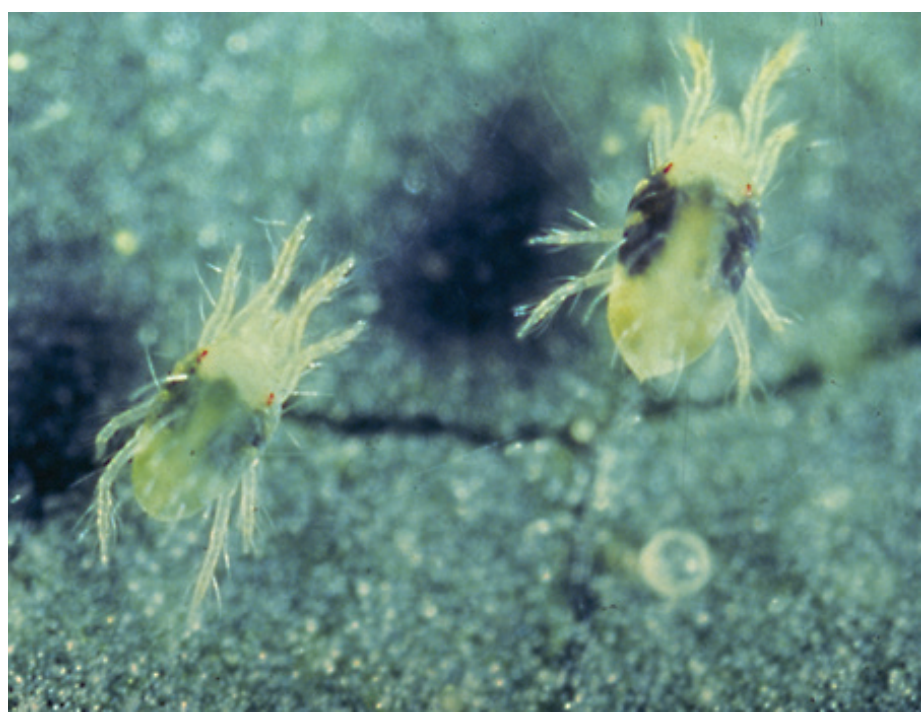

Figure 8. Deuronymph (left) and mature female (right) twospotted spider mites.

Credits: Lance Osborne, UF/IFAS

\section{Azalea Gall (Exobasidium vaccinii) RECOGNITION}

Leaves, flower parts, branch tips, and even seedpods are all affected by this fungus. Infected leaves develop fleshy galls ranging in color from pale green to pink to white and even brown. Flower parts can become so thickened that the whole bloom is turned into a hard, fleshy or waxy, irregularly shaped gall.

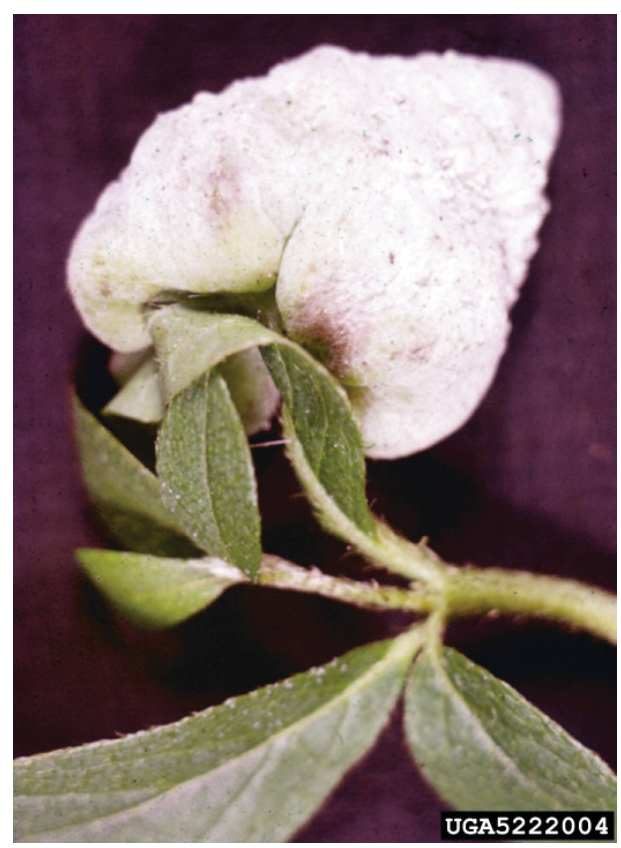

Figure 9. Exobasidium vaccinii grows on an azalea leaf and flower. Credits: Florida Division of Plant Industry, Florida Department of Agriculture and Consumer Services, Bugwood.org (https://www. ipmimages.org/browse/detail.cfm?imgnum=5222004) 


\section{CONTRIBUTING FACTORS}

After overwintering in the plant, infection occurs early in the spring on actively growing plant parts. The seriousness of this disease can vary due to environmental conditions, with cool, wet spring weather causing more incidence of the disease. Spores are produced on infected leaves during spring and summer and are dispersed via air and water. Dense plantings in overly shaded areas with little air circulation provide conditions for the fungus to thrive. This condition is typically not a problem unless wet conditions prevail for extended periods of time.

\section{MANAGEMENT RECOMMENDATIONS}

Remove obvious galls. Galls should be hand-pruned and destroyed before they turn white. Be sure to clean the pruners with a quaternary ammonia product to stop the spread of the disease from one plant to another. The mulch layer below plants can harbor the overwintering fungus and may be removed in mid-fall to minimize reinfection in the spring, if severity of the problem warrants (Cornell University 2018).

\section{Cercospora Leaf Spot (Pseudocercospora handelii) RECOGNITION}

Circular to angular dark brown leaf spots occur on both sides of leaves. The spots may coalesce, especially along the margins. Under moist conditions, the fungus sporulates on both leaf surfaces, and greenish-brown fruiting stalks can be seen. When severe, chlorosis and defoliation can occur.

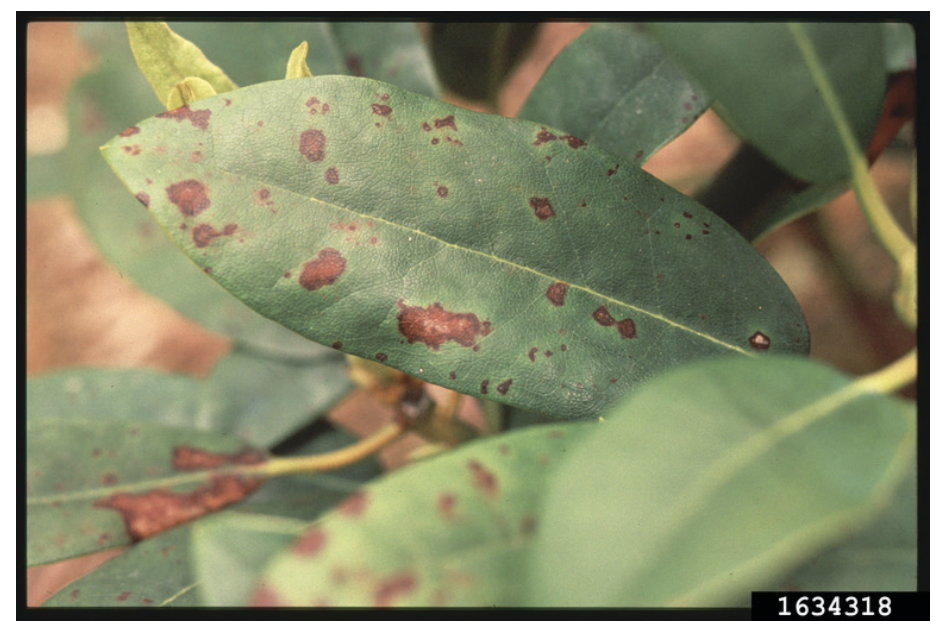

Figure 10. Azalea leaves showing symptoms of Cercospora leaf spot. Credits: Penn State Department of Plant Pathology \& Environmental Microbiology Archives, Penn State University, Bugwood.org (https:// www.ipmimages.org/browse/detail.cfm?imgnum=1634318)

\section{CONTRIBUTING FACTORS}

Cercospora leaf spot is most troublesome in late summer and fall, or whenever periods of warm temperatures and high humidity or leaf wetness occur.

\section{MANAGEMENT RECOMMENDATIONS}

Avoid frequent overhead irrigation, remove fallen leaves, and keep leaves dry when watering plants. Apply approved fungicides to the undersides of leaves and make sure to spray during periods of high humidity to prevent serious foliage damage (Clemson University 2017).

\section{Armillaria Root Rot (Armillaria tabescens) RECOGNITION}

Mushroom root rot causes a slow decline that can take a year or more to kill the plant. Symptoms begin with chlorosis of foliage on the lower branches and progressive thinning of the canopy. Usually, during the high temperatures of summer, plants will desiccate quickly and hold onto their dry, grey-green leaves. Single-stemmed plants can be killed outright, while multi-stemmed plants may partially survive. An examination below the bark at the soil line will reveal the creamy white mycelium of the fungus. After the plant has died, the honey- colored mushrooms may appear in the area of the dead trunk.

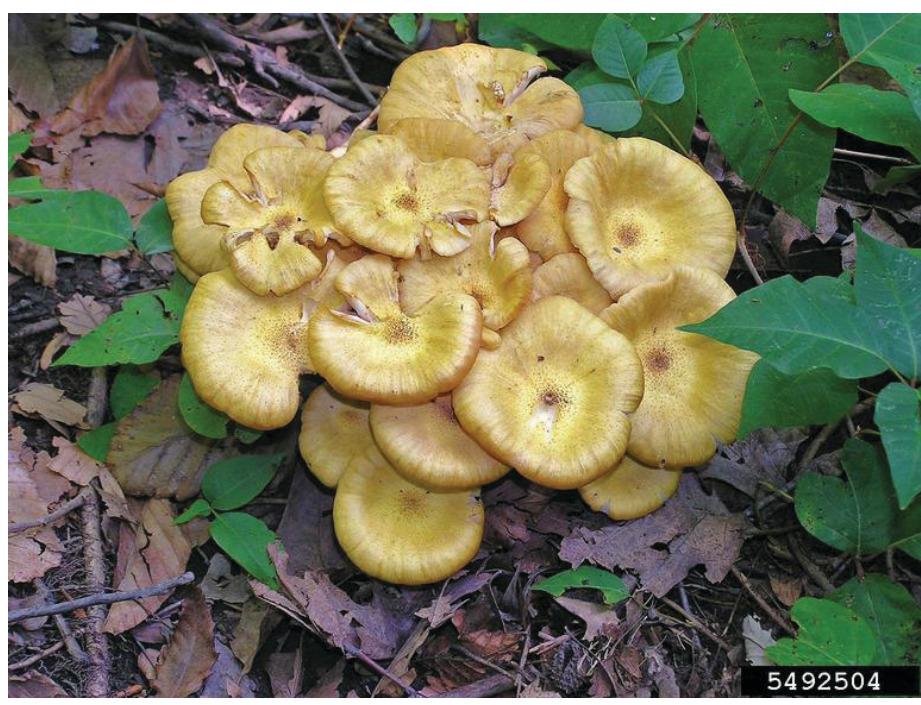

Figure 11. Armillaria root rot fruiting bodies. Notice the tight cluster that shares a basal anchor to the ground.

Credits: Curtis E. Young, Ohio State University, Bugwood.org (https:// www.ipmimages.org/browse/detail.cfm?imgnum=5492504)

\section{CONTRIBUTING FACTORS}

A soilborne fungus, mushroom root rot has a wide host range. It can attack apparently healthy plants. It may spread to adjacent plants through root grafts. 


\section{MANAGEMENT RECOMMENDATIONS}

There is no control. Remove diseased plants and roots. Avoid replanting with other susceptible species, and/ or replace soil before replanting (UF/IFAS Gardening Solutions).

\section{Ovulinia Petal Blight (Ovulinia azalea) RECOGNITION}

Symptoms begin as small, water-soaked spots on the flower petals. The brown lesions rapidly enlarge and become slimy, and entire petals become blighted. Infected flowers turn prematurely brown but usually remain on the plant longer than non-infected flowers.

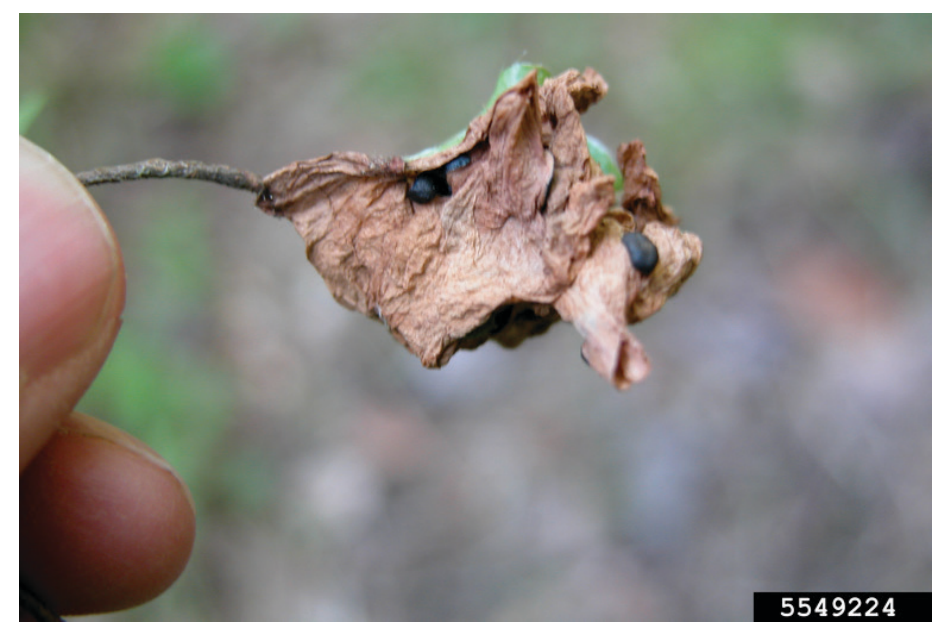

Figure 12. Symptoms of petal blight on azalea.

Credits: Penn State Department of Plant Pathology \& Environmental Microbiology Archives, Penn State University, Bugwood.org (https:// www.ipmimages.org/browse/detail.cfm?imgnum=5549224)

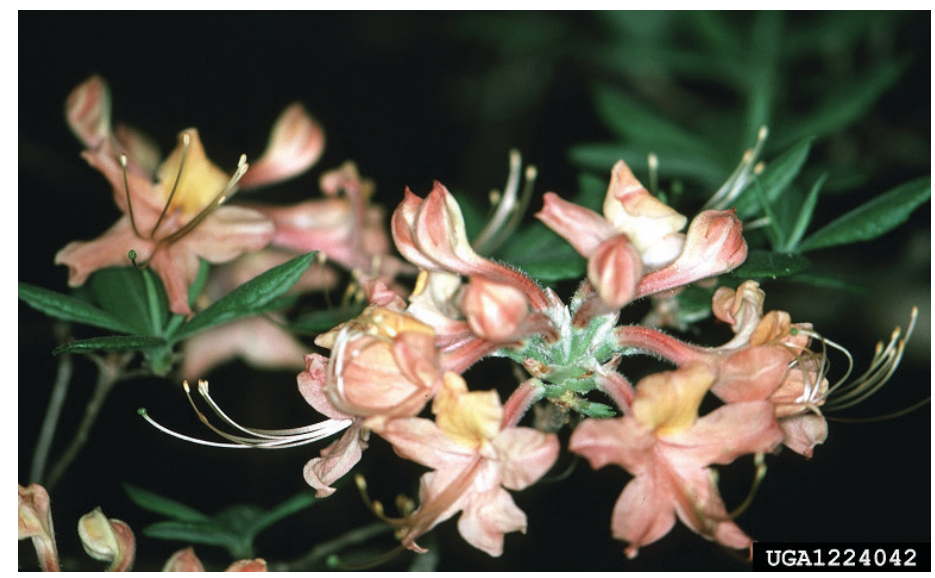

Figure 13. Azalea petals showing petal blight symptoms. Credits: Jerry A. Payne, USDA Agricultural Research Service, Bugwood.org (https://www.ipmimages.org/browse/detail. cfm?imgnum =1224042)

\section{CONTRIBUTING FACTORS}

The pathogen overwinters as sclerotia in diseased flowers on the plants or lying on the soil surface. About the same time as azaleas flower, the sclerotia germinate and produce spores which are the primary source of new infections. Spore germination is optimum at $64^{\circ} \mathrm{F}$ with periods of heavy mist or dew.

\section{MANAGEMENT RECOMMENDATIONS}

Remove plant litter and use mulch to inhibit germination of sclerotia. Use of fungicides is not usually justified economically, but reduction in disease severity can be achieved with weekly sprays starting at bud break (University of California 2017).

\section{Wet Root Rots (Phytophthora spp. and Pythium) \\ RECOGNITION}

Plants exhibit poor growth, thinning of the foliage canopy, yellowing and loss of older leaves, and eventual branch or plant death. The roots are dark and rotted. Wood under bark at the soil line becomes discolored, while roots become discolored and rotten (Pythium). Basal stems can also rot (Phytophthora). Wet rots cause a soft decay of the outer layers of roots, which can be easily stripped off between two fingers, leaving the firm, white stele intact.

\section{CONTRIBUTING FACTORS}

The disease is triggered by periods of excessive soil moisture, which provides an incubator for soil molds. Conditions that favor disease development include planting too deep, poor drainage, shallow rooting, and poor water management.

\section{MANAGEMENT RECOMMENDATIONS}

Correct cultural problems, remove infected plants, and correct any overwatering. Apply an approved fungicide if the problem is diagnosed early and cultural problems corrected (University of California 2009). 


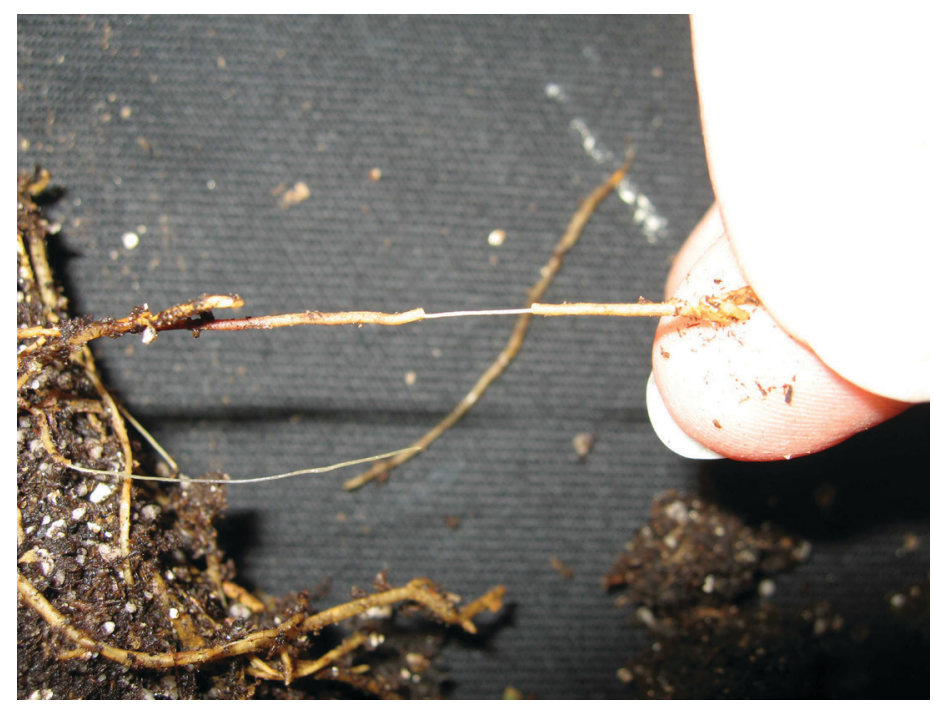

Figure 14. Root slip caused by root rot disease.

Credits: Juanita Popenoe, UF/IFAS

\section{Iron Chlorosis RECOGNITION}

New growth becomes yellow but veins remain green. In severe cases, leaves turn entirely white and can develop marginal leaf burn or tip burn.

\section{CONTRIBUTING FACTORS}

High soil pH (above 6.5) is a common cause of iron deficiency, since iron is less available at high $\mathrm{pH}$. Poor aeration and subsequent poor root function may also cause the plant to be deficient in iron.

\section{MANAGEMENT RECOMMENDATIONS}

The most desirable $\mathrm{pH}$ for growing azaleas is in the range of 5.0 to 5.5. Check the soil $\mathrm{pH}$ before choosing the acidloving azalea. In some cases, $\mathrm{pH}$ may be effectively lowered with applications of elemental sulfur; however, it is not practical to continuously battle the high $\mathrm{pH}$ of calcareous soils. For existing plantings, use acid-forming fertilizers with iron. Additional soil and/or foliar applications of iron may help.

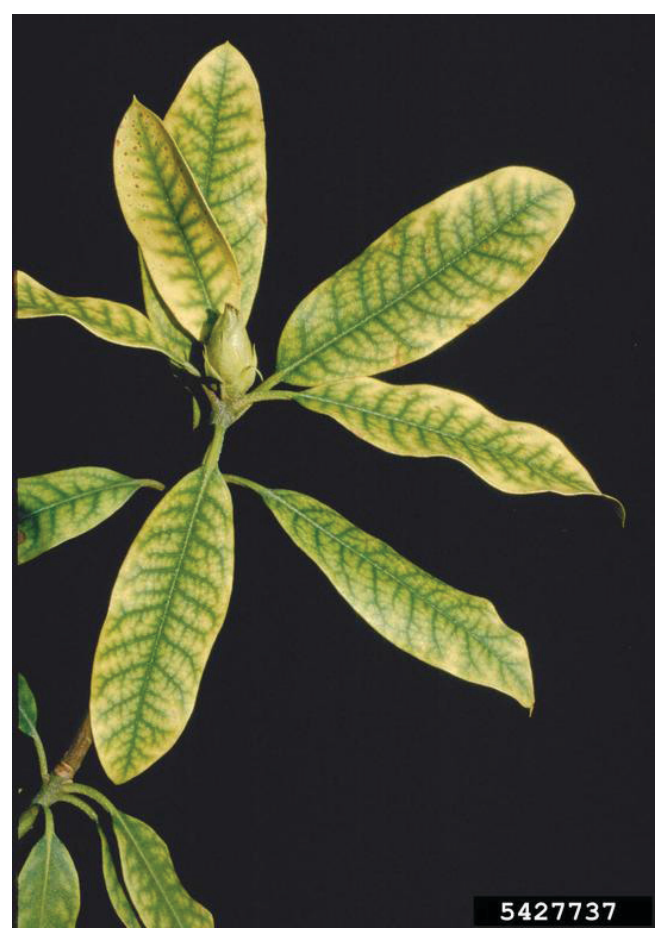

Figure 15. Azalea leaves showing symptoms of interveinal chlorosis due to iron deficiency.

Credits: Cheryl Kaiser, University of Kentucky, Bugwood.org (https:// www.ipmimages.org/browse/detail.cfm?imgnum=5427737)

\section{Planting Depth RECOGNITION}

Roots are deprived of oxygen when planted too deeply. Above-ground symptoms are similar to root rot chlorotic foliage, lack of growth, thinning of the canopy, and a general slow decline.

\section{CONTRIBUTING FACTORS}

Improper planting is the cause; no soil should be placed on top of the root ball. Excessive mulch may also be a factor.

\section{MANAGEMENT RECOMMENDATIONS}

Replanting at the correct depth may allow the plant to recover if the problem is caught early. Pull back and/or remove excess mulch from the base of the plant.

\section{References}

Brown, S. P. 2003. Azaleas at a glance. ENH37. Gainesville: University of Florida Institute of Food and Agricultural Sciences. https://edis.ifas.ufl.edu/mg019

Clemson University. 2017. "Azalea \& Rhododendron Diseases." https://hgic.clemson.edu/factsheet/ azalea-rhododendron-diseases/ 
Cornell University. 2018. "Azalea gall: Exobasidium vaccinii." http://plantclinic.cornell.edu/factsheets/azaleagall.pdf

Dekle, G. W. 2000. Azalea caterpillar, Datana major Grote \& Robinson (Insecta: Lepidoptera: Notodontidae). EENY137. Gainesville: University of Florida Institute of Food and Agricultural Sciences. http://edis.ifas.ufl.edu/in294

Dekle, G. W. 2007. Azalea leafminer, Caloptilia azaleella (Brants) (Insecta: Lepidoptera: Gracillariidae). EENY379. Gainesville: University of Florida Institute of Food and Agricultural Sciences. http://edis.ifas.ufl.edu/in736

Denmark, H. A., Welbourn, W. C. and Fasulo, T. R. 2006. Southern Red Mite, Oligonychus ilicis (McGregor) (Arachnida: Acari: Tetranychidae). EENY376. Gainesville: University of Florida Institute of Food and Agricultural Sciences. http://edis.ifas.ufl.edu/in680

Fasulo, T. R. and Denmark, H. A. 2000. Twospotted Spider Mite, Tetranychus urticae Koch (Arachnida: Acari: Tetranychidae). EENY150. Gainesville: University of Florida Institute of Food and Agricultural Sciences. http://edis.ifas. ufl.edu/in307

Gyeltshen, J. and Hodges, A. 2006. "Azalea lace bug, Stephanitis pyrioides (Scott) (Insecta: Hemiptera: Tingidae)." http://entnemdept.ufl.edu/creatures/orn/shrubs/ azalea_lace_bug.htm

UF/IFAS Gardening Solutions. 2017. "Armillaria root rot." http://gardeningsolutions.ifas.ufl.edu/care/pests-anddiseases/diseases/armillaria-root-rot.html

University of California. 2009. "Azalea (Rhododendron spp.) disease control outlines." http://ipm.ucanr.edu/PMG/ r280110211.html

University of California. 2017. "Azalea and rhododendron petal blight - Ovulinia azalea." http://ipm.ucanr.edu/PMG/ GARDEN/PLANTS/DISEASES/flowerblight.html 